\title{
Preparation of $\mathrm{Gd}_{2} \mathrm{O}_{3}: \mathrm{Eu}^{3+}$ downconversion luminescent material and its application in dye-sensitized solar cells
}

\author{
LI QingBei, LIN JianMing*, WU JiHuai, LAN Zhang, WANG JiangLi, WANG Yue, \\ PENG FuGuo, HUANG MiaoLiang \& XIAO YaoMing
}

Engineering Research Center of Environment-Friendly Functional Materials of the Ministry of Education, the Key Laboratory for Functional Materials of Fujian Higher Education, Institute of Material Physical Chemistry, Huaqiao University, Quanzhou 362021, China

Received January 13, 2011; accepted April 22, 2011

\begin{abstract}
$\mathrm{Gd}_{2} \mathrm{O}_{3}: \mathrm{Eu}^{3+}$ downconversion luminescent powder was prepared using the homogeneous precipitation method. Its optical properties were analyzed and it was introduced into a dye-sensitized solar cell (DSSC). As a luminescence medium, $\mathrm{Gd}_{2} \mathrm{O}_{3}: \mathrm{Eu}^{3+} \mathrm{im}^{-}$ proved light harvesting via conversion luminescence and increased the photocurrent of the DSSC. As a p-type dopant insulating rare earth oxides form an energy barrier, and the $\mathrm{Gd}_{2} \mathrm{O}_{3}: \mathrm{Eu}^{3+}$ elevated the energy level of the oxide film and increased the photovoltage. The photoelectric conversion efficiency for a DSSC with $\mathrm{Gd}_{2} \mathrm{O}_{3}: \mathrm{Eu}^{3+}$ doping $(6: 100)$ reached $7.01 \%$, which was $17.4 \%$ higher than the photoelectrical conversion efficiency of a DSSC without $\mathrm{Gd}_{2} \mathrm{O}_{3}: \mathrm{Eu}^{3+}$ doping.
\end{abstract}

dye-sensitized solar cell, downconversion, rare-earth oxide, luminescent material, p-type doping

Citation: $\quad \mathrm{Li} \mathrm{Q} \mathrm{B,} \mathrm{Lin} \mathrm{J} \mathrm{M,} \mathrm{Wu} \mathrm{J} \mathrm{H,} \mathrm{et} \mathrm{al.} \mathrm{Preparation} \mathrm{of} \mathrm{Gd}_{2} \mathrm{O}_{3}: \mathrm{Eu}^{3+}$ downconversion luminescent material and its application in dye-sensitized solar cells. Chinese Sci Bull, 2011, 56: 3114-3118, doi: 10.1007/s11434-011-4664-z

Considerable effort has been devoted to the dye-sensitized solar cell (DSSC) since the first prototype was reported by O'Regan et al. [1] and Gratzel [2]. There has been great progress in development of the DSSC over the past decade, because of its low cost, simple preparation, and conversion efficiency which has reached $11 \%$ [3]. In general, the sensitizer of the DSSC contains mainly N3 and N719 dyes [1-6], and the DSSC consists of a porous nanocrystalline $\mathrm{TiO}_{2}$ film sensitized by a dye for absorbing incident light. However, even the best of these dyes (N719) absorbs only visible light in the wavelength range $300-800 \mathrm{~nm}$, while the standard air-mass (AM1.5) terrestrial spectrum covers the wavelength region from UV to IR (200-2500 $\mathrm{nm})$. Downconversion materials are a viable option for reducing the spectral mismatch losses. Trupke et al. [7] have suggested that the dye molecules in a DSSC could avoid the absorption of high-energy photons in a conventional semiconductor solar cell with infinite bands, by directing the

*Corresponding author (email: jmlin@hqu.edu.cn) high-energy part of the solar spectrum toward a downconverter with suitable low-pass mirrors. However, few studies have been carried out on the use of conversion luminescence in the DSSC. Our group [8] has reported work in which $\mathrm{Y}_{2} \mathrm{O}_{3}: \mathrm{Eu}^{3+}$ nanophosphor was prepared by the co-precipitation method. As a luminescence medium $\mathrm{Y}_{2} \mathrm{O}_{3}: \mathrm{Eu}^{3+}$ improved light harvesting via a conversion luminescence process and increased the photocurrent. As a p-type dopant, $\mathrm{Y}_{2} \mathrm{O}_{3}: \mathrm{Eu}^{3+}$ elevated the energy level of the oxide film and increased the photovoltage.

In the present study, $\mathrm{Gd}_{2} \mathrm{O}_{3}: \mathrm{Eu}^{3+}$ nanophosphor was prepared by the homogeneous precipitation method $[9,10]$. Since $\mathrm{Gd}_{2} \mathrm{O}_{3}$ is isostructural with $\mathrm{Y}_{2} \mathrm{O}_{3}, \mathrm{Gd}_{2} \mathrm{O}_{3}: \mathrm{Eu}^{3+}$ can be used as a phosphor and is comparable to $\mathrm{Y}_{2} \mathrm{O}_{3}: \mathrm{Eu}^{3+}$. $\mathrm{Gd}_{2} \mathrm{O}_{3}: \mathrm{Eu}^{3+}$ has been reported to be a more effective phosphor than $\mathrm{Y}_{2} \mathrm{O}_{3}: \mathrm{Eu}^{3+}$ for particular applications such as an $\mathrm{X}$-ray scintillator, because $\mathrm{Gd}_{2} \mathrm{O}_{3}$ has higher density and light efficiency [11]. In addition, the synthesis of $\mathrm{Gd}_{2} \mathrm{O}_{3}: \mathrm{Eu}^{3+}$ phosphor with higher photoluminescence (PL) intensity than commercially available $\mathrm{Y}_{2} \mathrm{O}_{3}: \mathrm{Eu}^{3+}$ has been 
reported [12,13]. In the present study, $\mathrm{Gd}_{2} \mathrm{O}_{3}: \mathrm{Eu}^{3+}$ as a luminescence medium and p-type dopant was introduced into the DSSC to improve photocurrent, photovoltage and solar conversion efficiency.

\section{Experimental}

\subsection{Materials}

Tetrabutyl titanate, absolute ethyl alcohol, glacial acetic acid, polyethylene glycol 20000, 4-tert-butylpyridine (TBP), nitric acid, OP emulsification agent (Triton X-100), iodine, lithium iodide, urea and ammonium hydroxide were analytical grade materials supplied by Shanghai Chemical Agent Ltd., Shanghai, China. Gadolinium oxide and europium oxide with purity $99.99 \%$ and $99.999 \%$ respectively, were supplied by Shanghai Yuelong Non-Ferrous Metals Limited, Shanghai, China. The sensitized dye N-719 (RuL2(NCS)2, $\mathrm{L}=4,4^{\prime}$-dicarboxylate-2,2'-bipyridine) was from SOLARONIX SA (Aubonne, Switzerland).

\subsection{Preparation of $\mathrm{Gd}_{2} \mathrm{O}_{3}: \mathrm{Eu}^{3+}$ nanophosphor}

$\mathrm{Gd}_{2} \mathrm{O}_{3}: \mathrm{Eu}^{3+}$ nanophosphor was prepared using the homogeneous precipitation technique by the following procedure $[9,10]$. Appropriate amounts of $\mathrm{Gd}_{2} \mathrm{O}_{3}$ and $\mathrm{Eu}_{2} \mathrm{O}_{3}$ were dissolved in dilute $\mathrm{HNO}_{3}$ solution. The $\mathrm{HNO}_{3}$ soluatin was made from a $1: 1(\mathrm{v} / \mathrm{v})$ mixture of deionized water and $60 \%-65 \% \mathrm{HNO}_{3}$ solution. After heating and evaporating the excess water and $\mathrm{HNO}_{3}$ until nitrate crystals emerged, the required amount of water was added to form $0.05 \mathrm{~mol} / \mathrm{L}$ $\mathrm{Gd}\left(\mathrm{NO}_{3}\right)_{3}$ and $0.05 \mathrm{~mol} / \mathrm{L} \mathrm{Eu}\left(\mathrm{NO}_{3}\right)_{3}$ aqueous soluations. The required volumes of the $\mathrm{Gd}\left(\mathrm{NO}_{3}\right)_{3}$ and $\mathrm{Eu}\left(\mathrm{NO}_{3}\right)_{3}$ soluations were then mixed to give a solution with the mole ratio $\mathrm{Gd}\left(\mathrm{NO}_{3}\right)_{3}: \mathrm{Eu}\left(\mathrm{NO}_{3}\right)_{3}=100: 6$. Excess $0.2 \mathrm{~mol} / \mathrm{L}$ urea solution was mixed with the $\mathrm{Gd}\left(\mathrm{NO}_{3}\right)_{3} / \mathrm{Eu}\left(\mathrm{NO}_{3}\right)_{3}$ solution, and sufficient aqueous ammonium hydroxide was added to adjust the $\mathrm{pH}$ to $8-9$. The resulting solution was heated in a water bath at $90^{\circ} \mathrm{C}$, and refluxed for $5 \mathrm{~h}$ after a precipitate started to form. The reaction mixture was then quenched in ice water, the precipitated precursor powder was washed with water and ethyl alcohol to eliminate residual salts. The powder was vacuum dried at $80^{\circ} \mathrm{C}$ for $24 \mathrm{~h}$, then calcined at $800^{\circ} \mathrm{C}$ for $2 \mathrm{~h}$, for subsequent use as a nanophosphor.

\subsection{Preparation of film electrodes of DSSC}

A $\mathrm{TiO}_{2}$ colloid was prepared according to the method developed by our group [14-17]. Varying amounts of $\mathrm{Gd}_{2} \mathrm{O}_{3}: \mathrm{Eu}^{3+}$ nanophosphor were dispersed in $\mathrm{TiO}_{2}$ sol, ultrasonicated and stirred for $30 \mathrm{~min}$, then hydrothermally treated to form a $\mathrm{TiO}_{2}+\mathrm{Gd}_{2} \mathrm{O}_{3}: \mathrm{Eu}^{3+}$ colloid. A film with thickness about $12 \mu \mathrm{m}$ was prepared by coating $\mathrm{TiO}_{2}$ colloid on an fluorine doped tin oxide coated glass (FTO) using a doctor blade and sintering at $450^{\circ} \mathrm{C}$ for $30 \mathrm{~min}$, then a
$\mathrm{TiO}_{2}+\mathrm{Gd}_{2} \mathrm{O}_{3}: \mathrm{Eu}^{3+}$ layer with thickness of about $4 \mu \mathrm{m}$ was coated on the $\mathrm{TiO}_{2}$ film by the same method. After sintering at $450^{\circ} \mathrm{C}$ for $30 \mathrm{~min}$ and soaking in $\mathrm{N}-719$ dye solution for $24 \mathrm{~h}$, a dye sensitized film electrode $\left(\mathrm{TiO}_{2}+\mathrm{Gd}_{2} \mathrm{O}_{3}: \mathrm{Eu}^{3+}\right)$ was obtained. For comparison, a dye-sensitized $\mathrm{TiO}_{2}$ film electrode without $\mathrm{Gd}_{2} \mathrm{O}_{3}: \mathrm{Eu}^{3+}$ was also made. The thickness of the oxide films for the DSSC with and without $\mathrm{Gd}_{2} \mathrm{O}_{3}: \mathrm{Eu}^{3+}$ were about $16 \mu \mathrm{m}$. DSSCs with and without the $\mathrm{Gd}_{2} \mathrm{O}_{3}: \mathrm{Eu}^{3+}$ bearing layer were assembled using the methods described previously [17].

\subsection{Characterization and measurements}

Powder X-ray diffraction (XRD) patterns were recorded with an X-ray diffractometer (Bruker D8, Karlsruhr, Germany) using $\mathrm{Cu} \mathrm{K} \alpha$ radiation $(\lambda=1.5405 \AA$ ). Micrographs were recorded using a field emission scanning electron microscope (SEM, S-4800, Hitachi, Japan). Photoluminescence spectra were obtained using a fluorescence spectrometer (FLS920, with excitation wavelength 263 nm, Edinburgh Instruments, UK). Photovoltaic tests of DSSCs were carried out by measuring the $I-V$ characteristic curves under simulated solar light irradiation of $100 \mathrm{~mW} / \mathrm{cm}^{2}$ from a 100 W Xe lamp (XQ-500W, Shanghai Photoelectricity Device Company, Shanghai, China).

Mott-Schottky analysis was carried out using standard electrochemical impedance spectroscopy at $1000 \mathrm{~Hz}$ in acetonitrile solution of containing $0.1 \mathrm{~mol} / \mathrm{L}$ lithium perchlorate, $10 \mathrm{mmol} / \mathrm{L}$ lithium iodide and $1 \mathrm{mmol} / \mathrm{L}$ iodine, by scanning the potential from the positive to the negative direction in steps of $5 \mathrm{mV} / \mathrm{s}$ at room temperature. The $\mathrm{TiO}_{2}$ thin film on FTO glass was the photoanode, the cathode was Pt foil, and a silver/silver chloride $(\mathrm{Ag} / \mathrm{AgCl})$ microelectrodes was used as reference electrode.

\section{Results and discussion}

\section{$2.1 \mathrm{Gd}_{2} \mathrm{O}_{3}: \mathrm{Eu}^{3+}$ nanophosphor}

Figure 1 shows a typical XRD pattern of $\mathrm{Gd}_{2} \mathrm{O}_{3}: \mathrm{Eu}^{3+}$ phosphor calcined at $800^{\circ} \mathrm{C}$ in air. It is basically consistent with the standard X-ray diffraction card JCPDS 12-0797 without any impurity peaks, indicating $\mathrm{Gd}_{2} \mathrm{O}_{3}$ with pure cubic structure. An SEM image of the powders is shown in Figure 2, and reveals that the particle size was $30-60 \mathrm{~nm}$.

\subsection{The properties of $\mathrm{Gd}_{2} \mathrm{O}_{3}: \mathrm{Eu}^{3+}$ nanophosphor}

Excitation spectra and emission spectra of $\mathrm{Gd}_{2} \mathrm{O}_{3}: \mathrm{Eu}^{3+}$ nanophosphor are shown in Figures 3 and 4. The spectral properties are typical of the well-known $\mathrm{Gd}_{2} \mathrm{O}_{3}: \mathrm{Eu}^{3+}$ [18-20]. The excitation spectrum was obtained by monitoring the emission of the $\mathrm{Eu}^{3+5} \mathrm{D}_{0} \rightarrow{ }^{7} \mathrm{~F}_{2}$ transition at $611 \mathrm{~nm}$. It can be seen clearly that the excitation spectrum (Figure 3 ) consists of a broad band with a maximum at $256 \mathrm{~nm}$ due to 


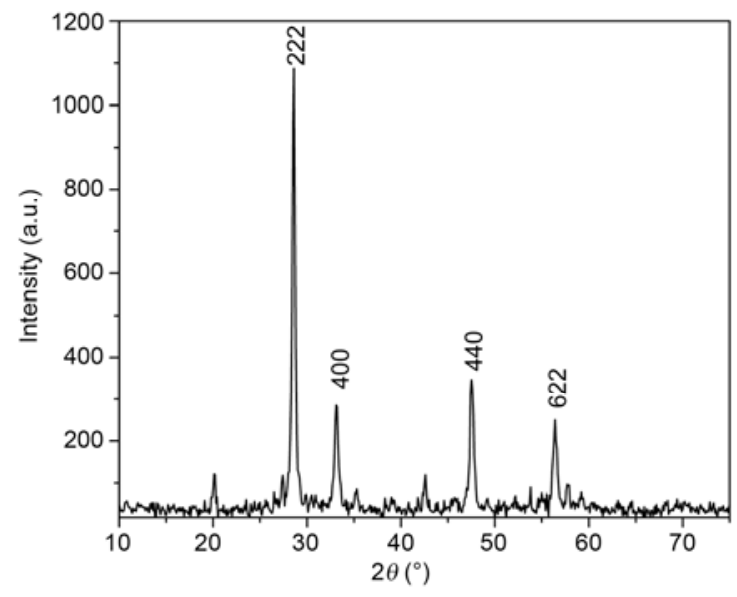

Figure 1 XRD pattern of the prepared $\mathrm{Gd}_{2} \mathrm{O}_{3}: \mathrm{Eu}^{3+}$ nanophosphor.

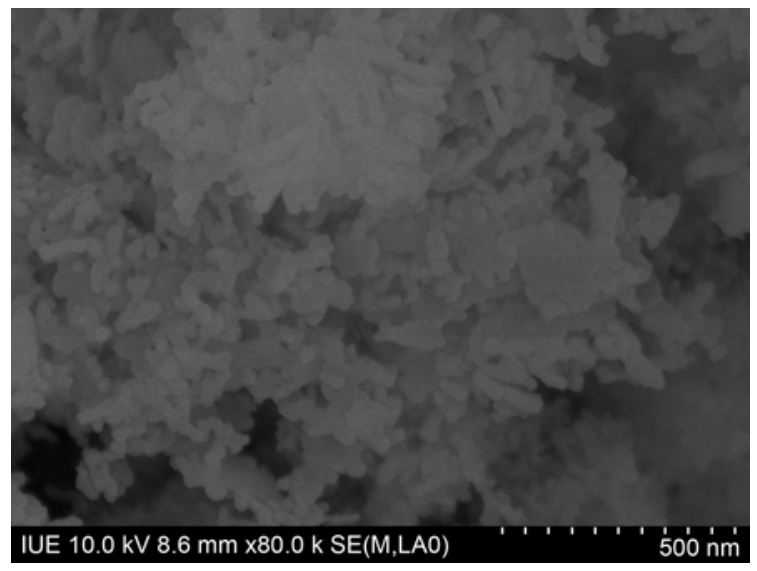

Figure 2 The SEM picture of $\mathrm{Gd}_{2} \mathrm{O}_{3}: \mathrm{Eu}^{3+}$ nanophosphor.

the charge-transfer band (CTB) between $\mathrm{O}^{2-}$ and $\mathrm{Eu}^{3+}$. The sharp peaks at $308 \mathrm{~nm}$ and the weak shoulder at $275 \mathrm{~nm}$ superimposed on the CTB of $\mathrm{Eu}^{3+}$ can be attributed to the $\mathrm{Gd}_{2} \mathrm{O}_{3}$ host excitation band, the ${ }^{8} \mathrm{~S}-{ }^{6} \mathrm{P}$, and ${ }^{8} \mathrm{~S}-{ }^{6} \mathrm{I}$ transition lines of $\mathrm{Gd}^{3+}$, respectively [21]. The presence of the $\mathrm{Gd}_{2} \mathrm{O}_{3}$ host band and $\mathrm{Gd}^{3+}$ excitation lines in the excitation spectrum of $\mathrm{Eu}^{3+}$ indicates that there is energy transfer from the $\mathrm{Gd}_{2} \mathrm{O}_{3}$ host and $\mathrm{Gd}^{3+}$ to $\mathrm{Eu}^{3+}$. In the longer wavelength region, the $\mathrm{f}-\mathrm{f}$ transition lines of $\mathrm{Eu}^{3+}$ (assigned in Figure 3) can be observed with very weak intensity compared with the $\mathrm{Eu}^{3+}-\mathrm{O}^{2-} \mathrm{CTB}$. Upon excitation into the CTB of $\mathrm{Eu}^{3+}$ at $263 \mathrm{~nm}$, the resulting emission spectrum is composed of ${ }^{5} \mathrm{D}_{0,1,2} \rightarrow{ }^{7} \mathrm{~F}_{J}(J=0,1,2,3,4)$ transition lines of $\mathrm{Eu}^{3+}$, with the ${ }^{5} \mathrm{D}_{0} \rightarrow{ }^{7} \mathrm{~F}_{2}$ hypersensitive transition $(611 \mathrm{~nm})$ being the most prominent group (Figure 4$)$. All of the other emission peaks at $534\left({ }^{5} \mathrm{D}_{1} \rightarrow{ }^{7} \mathrm{~F}_{1}\right), 580\left({ }^{5} \mathrm{D}_{0} \rightarrow{ }^{7} \mathrm{~F}_{0}\right), 588,593,599\left({ }^{5} \mathrm{D}_{0} \rightarrow{ }^{7} \mathrm{~F}_{1}\right)$, $651\left({ }^{5} \mathrm{D}_{0} \rightarrow{ }^{7} \mathrm{~F}_{3}\right)$, and $708 \mathrm{~nm}\left({ }^{5} \mathrm{D}_{0} \rightarrow{ }^{7} \mathrm{~F}_{4}\right)$ are assigned in Figure 4. The presence of emission lines from higher excited states of $\mathrm{Eu}^{3+}\left({ }^{5} \mathrm{D}_{1},{ }^{5} \mathrm{D}_{2}\right)$ is attributed to the low vibration energy of the $\mathrm{Gd}-\mathrm{O}$ band $\left(545 \mathrm{~cm}^{-1}\right)$. Multiphonon relaxation by Gd-O vibration is not able to completely bridge the gaps

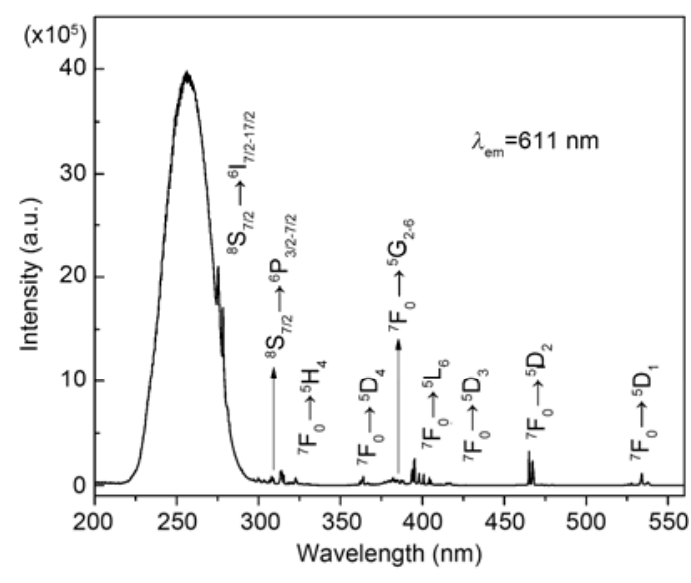

Figure 3 The excitation spectra of $\mathrm{Gd}_{2} \mathrm{O}_{3}: \mathrm{Eu}^{3+}$ nanophosphor.

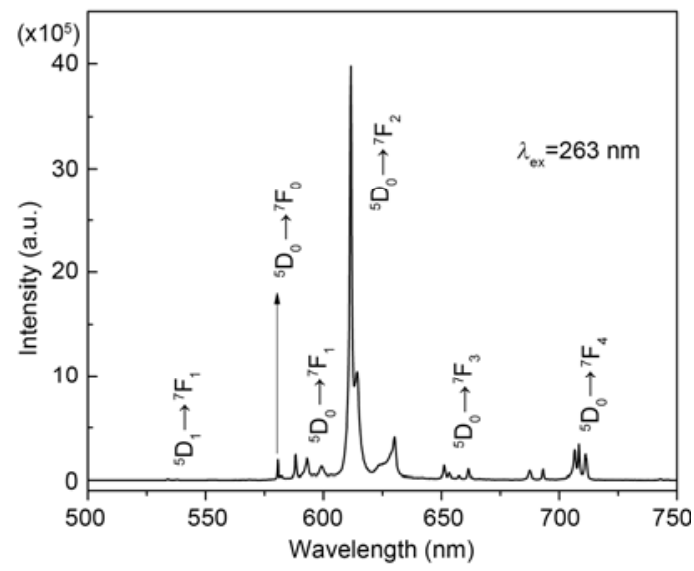

Figure 4 The emission spectra of $\mathrm{Gd}_{2} \mathrm{O}_{3}: \mathrm{Eu}^{3+}$ nanophosphor.

between the higher energy levels $\left({ }^{5} \mathrm{D}_{1},{ }^{5} \mathrm{D}_{2}\right)$ and the ${ }^{5} \mathrm{D}_{0}$ level of $\mathrm{Eu}^{3+}$, resulting in the emission from these levels [21].

\subsection{Photoelectric performance of DSSC}

To investigate the effect of ultraviolet irradiation, we used a filter (ZWB3) that only the light with wavelength less than $420 \mathrm{~nm}$ could pass through. Figures 5 and 6 show the photocurrent-voltage curves of DSSCs and the solar cells with no dye, and with and without $\mathrm{Gd}_{2} \mathrm{O}_{3}: \mathrm{Eu}^{3+}$ in $\mathrm{TiO}_{2}$ the electrode under the ultraviolet irradiation of $24 \mathrm{~mW} / \mathrm{cm}^{2}$. Figure 5 shows that the DSSC lacking the rare-earth ions as dopent had the following photovoltaic parameters: short-circuit current density $\left(J_{\mathrm{SC}}\right)=1.05 \mathrm{~mA} / \mathrm{cm}^{2}$, open-circuit voltage $\left(V_{\mathrm{OC}}\right)=0.591 \mathrm{~V}$, fill factor $(F F)=0.569$ and light-to-electric energy conversion efficiency $(\eta)=1.47 \%$. The DSSC containing the rare-earth ions as dopent displayed the enhanced photovoltaic parameters: $J_{\mathrm{SC}}=1.19 \mathrm{~mA} / \mathrm{cm}^{2}, V_{\mathrm{OC}}=0.679 \mathrm{~V}, F F=0.565$ and $\eta=1.90 \%$. Figure 6 indicates that with no dye in the solar cells, the cells lacking the rare-earth ions as dopent had the photovol 


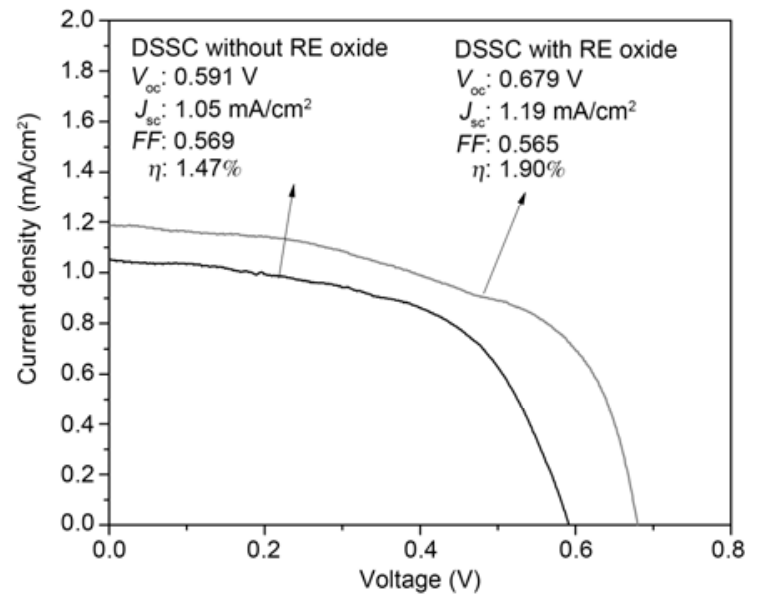

Figure 5 Current-Voltage curves of DSSCs under ultraviolet irradiation $\left(24 \mathrm{~mW} / \mathrm{cm}^{2}\right)$.

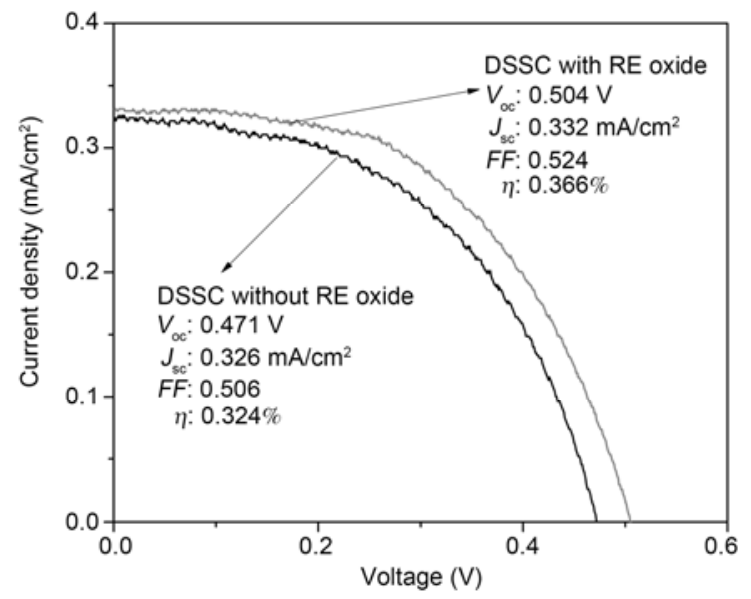

Figure 6 Current-Voltage curves of the solar cells when no dye under ultraviolet irradiation $\left(24 \mathrm{~mW} / \mathrm{cm}^{2}\right)$.

taic parameters: $J_{\mathrm{SC}}=0.326 \mathrm{~mA} / \mathrm{cm}^{2}, V_{\mathrm{OC}}=0.471 \mathrm{~V}, F F=0.506$ and $\eta=0.324 \%$. The solar cells containing the rare-earth ions as dopent displayed the enhanced photovoltaic parameters: $J_{\mathrm{SC}}=0.332 \mathrm{~mA} / \mathrm{cm}^{2}, V_{\mathrm{OC}}=0.504 \mathrm{~V}, F F=0.524$ and $\eta=0.366 \%$. The enhancement indicates that the rare-earth ions dopent converts ultraviolet light to visible light which the N-719 dye can absorb effectively, increasing the harvested sunlight and improving the efficiency of the DSSC.

The data in Figure 7 and Table 1 show that $J_{\mathrm{SC}}$ increased with the $\mathrm{Gd}_{2} \mathrm{O}_{3}: \mathrm{Eu}^{3+}$ dopent level up to 6:100 (the mole ratio of gadolinium and titanium), beyond which $J_{\mathrm{SC}}$ decreased. The increase in $J_{\mathrm{SC}}$ comes mainly from the ultraviolet response of $\mathrm{Gd}_{2} \mathrm{O}_{3}: \mathrm{Eu}^{3+}$ nanophosphor, which caused more to be harvested, thus increasing $J_{\mathrm{SC}}$ The decrease in $J_{\mathrm{SC}}$ at higher dopent levels is due to the fact that introduction of rare-earth oxides produced defects in the oxide film, which caused the recombination of photoinduced holes and electrons and hence decrease $J_{\mathrm{SC}}$ [22].

Figure 8 is a Mott-Schottky plot for the $\mathrm{TiO}_{2}$ electrode

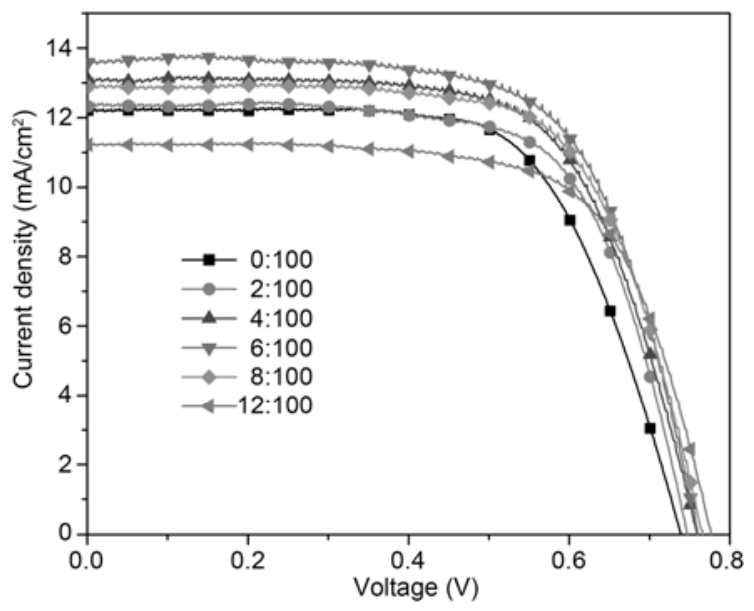

Figure 7 Current-Voltage curves of DSSCs without and with different ratio of $\mathrm{Gd}_{2} \mathrm{O}_{3}: \mathrm{Eu}^{3+}$ nanophosphor in $\mathrm{TiO}_{2}$ electrode.

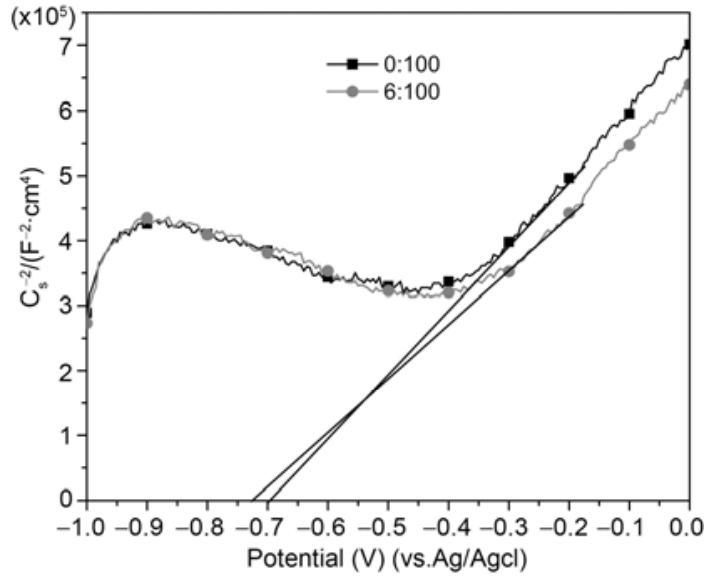

Figure 8 Mott-Schottky plots of $\mathrm{TiO}_{2}$ electrode with and without doped nanophosphor.

with and without doped nanophosphor. It is clear from Figure 8 that under the same conditions, the $\mathrm{TiO}_{2}$ working electrode of $\mathrm{TiO}_{2}$ had similar flatband potential with $(-0.723 \mathrm{~V})$ or without $(-0.692 \mathrm{~V})$ nanophosphor. Figure 8 also shows that the slope of the linear region of the Mott-Schottky curve desreased when the nanophosphor was doped, thus increasing its charge carriers density.

On the other hand, the $V_{\mathrm{OC}}$ increased with increasing amount of $\mathrm{Gd}_{2} \mathrm{O}_{3}: \mathrm{Eu}^{3+}$. When the mole ratio of element gadolinium and titanium was $12: 100, V_{\mathrm{OC}}$ reached $0.776 \mathrm{~V}$, which is the highest value yet observed in a DSSC, indicating the significance of p-type doping. According to Gratzel [2], $V_{\mathrm{OC}}$ corresponds to the difference between the energy level of the electrons in the oxide film and the redox potential of the electrolyte. When rare-earth ions are doped and substitute for the $\mathrm{Ti}^{4+}$ ion lattice sites in $\mathrm{TiO}_{2}$, giving a p-type doping similar to that in Si semiconductors, the energy level of the oxide film is elevated, which leads to the increase of $V_{\mathrm{oc}}$. Similar phenomena were observed by Ko et al. 
Table 1 Influence of $\mathrm{Gd}_{2} \mathrm{O}_{3}: \mathrm{Eu}^{3+}$ nanophosphor on photoelectric parameters of DSSC

\begin{tabular}{ccccc}
\hline Mole ratio $\left(N_{\mathrm{Gd}}: N_{\mathrm{Ti}}\right)$ & $J_{\mathrm{sc}}\left(\mathrm{mA} / \mathrm{cm}^{2}\right)$ & $V_{\mathrm{oc}}(\mathrm{V})$ & $F F$ & $\eta(\%)$ \\
\hline $0: 100$ & 12.30 & 0.739 & 0.657 & 5.97 \\
$2: 100$ & 12.47 & 0.747 & 0.677 & 6.31 \\
$4: 100$ & 13.18 & 0.759 & 0.667 & 6.68 \\
$6: 100$ & 13.79 & 0.76 & 0.669 & 7.01 \\
$8: 100$ & 12.93 & 0.766 & 0.685 & 6.78 \\
$12: 100$ & 11.25 & 0.776 & 0.687 & 5.99 \\
\hline
\end{tabular}

[23] who found that Al-doping of the $\mathrm{TiO}_{2}$ electrode increased $V_{\text {oc }}$, while $\mathrm{W}$-doping had the opposite effect (n-type doping). Yang et al. [24,25] found that an energy barrier was formed when the $\mathrm{TiO}_{2}$ electrode was modified with a rare earth ion layer of a certain thickness. The energy barrier efficiently suppressed charge recombination. As a result, the photovoltage and photoelectrical conversion efficiency were improved under optimal conditions.

The solar conversion efficiency for a DSSC with $\mathrm{Gd}_{2} \mathrm{O}_{3}: \mathrm{Eu}^{3+}$ (6:100) doped nanophosphor reached $7.01 \%$, which is $17.4 \%$ higher than for a DSSC without $\mathrm{Gd}_{2} \mathrm{O}_{3}: \mathrm{Eu}^{3+}$ nanophosphor doping (Figure 7). Furthermore, by choosing a suitable doping ion and concentration as a p-type luminescence medium, it is possible to further increase the conversion efficiency of the DSSC.

\section{Conclusion}

In summary, $\mathrm{Gd}_{2} \mathrm{O}_{3}: \mathrm{Eu}^{3+}$ nanophosphor was introduced into a dye-sensitized solar cell. As a luminescence medium, $\mathrm{Gd}_{2} \mathrm{O}_{3}: \mathrm{Eu}^{3+}$ improved light harvesting via a conversion luminescence process and increased photocurrent. As a p-type dopant insulating rare earth oxides form an energy barrier, and the $\mathrm{Gd}_{2} \mathrm{O}_{3}: \mathrm{Eu}^{3+}$ elevated the energy level of the oxide film and increased the photovoltage. The solar conversion efficiency for a DSSC with $\mathrm{Gd}_{2} \mathrm{O}_{3}: \mathrm{Eu}^{3+}$ doping $(6: 100)$ reached $7.01 \%$, which is $17.4 \%$ higher than for a DSSC without $\mathrm{Gd}_{2} \mathrm{O}_{3}: \mathrm{Eu}^{3+}$ nanophosphor doping.

This work was supported by the National High Technology Research and Development Program of China (2009AA03Z217) and the National Natural Science Foundation of China (90922028, 50842027).

1 O'Regan B, Gratzel M. A low-cost high-efficiency solar cell based on dye-sensitized colloidal $\mathrm{TiO}_{2}$ films. Nature, 1991, 353: 737-740

2 Gratzel M. Photoelectrochemical cells. Nature, 2001, 414: 338-345

3 Gratzel M. Solar energy conversion by dye-sensitized photovoltaic cells. Inorg Chem, 2005, 44: 6841-6851

4 Gratzel M. Engineering of a novel ruthenium sensitizer and its application in dye-sensitized solar cells for conversion of sunlight into electricity. Inorg Chem, 2005, 44: 178-180
5 Lee S A, Abrams N M, Hoertz P G, et al. Compling of titania inverse opals to nanocrystalline titania layers in dye-sensitized solar cells. J Phys Chem B, 2008, 112: 14415-14421

6 Nazeeruddin M K, Kay A, Rodicio I, et al. Conversion of light to electricity by cis-bis (2,2'-bipyridyl-4,4-dicarboxylate) ruthenium (II) charge-transfer sensitizers $\left(X=\mathrm{Cl}^{-}, \mathrm{Br}^{-}, \mathrm{I}^{-}, \mathrm{CN}^{-}\right.$and $\left.\mathrm{SCN}^{-}\right)$on nanocrystalline $\mathrm{TiO}_{2}$ elextrodes. J Am Chem Soc, 1993, 115: 6382-6390

7 Trupke T, Green M A, Wurfel P. Improving solar cell efficiency by down-conversion of high-energy photons. J Appl Phys, 2002, 92: 1668-1674

8 Wu J H, Xie G X, Lin J M, et al. Enhancing photoelectrical performance of dye-sensitized solar cell by doping with europium-doped yttria rare-earth oxide. J Power Sources, 2010, 195: 6937-6940

9 Park I Y, Kim D J, Lee J W, et al. Effects of urea concentration and reaction temperature on morphology of gadolinium compounds prepared by homogeneous precipitation. Mater Chem Phys, 2007, 106: $149-157$

10 Liu G X, Hong G Y, Sun D X, et al. Preparation of spherical nanometer $\mathrm{Gd}_{2} \mathrm{O}_{3}$ :Eu luminescent materials (in Chinese). Chinese J Inorg Chem, 2004, 20: 1367-1370

11 Garcia-Murillo A, Luyer C L, Dujardin C, et al. Elaboration and scintillation properties of $\mathrm{Eu}^{3+}$-doped $\mathrm{Gd}_{2} \mathrm{O}_{3}$ and $\mathrm{Lu}_{2} \mathrm{O}_{3}$ sol-gel films. Nucl Inst Methods Phys Res Sec A, 2002, 486: 181-185

12 Park J C, Moon H K, Kim D K, et al. Morphology and cathodoluminescence of $\mathrm{Li}$-doped $\mathrm{Gd}_{2} \mathrm{O}_{3}: \mathrm{Eu}^{3+}$, a red phosphor operating at low voltages. Appl Phys Lett, 2000, 77: 2162-2164

13 Lim M A, Kang Y C, Park H D, et al. $\mathrm{Gd}_{2} \mathrm{O}_{3}$ :Eu phosphor particles prepared from the polymeric precursors in spray pyrolysis. J Electrochem Soc, 2001, 148: H171-H175

14 Wu J H, Hao S C, Lin J M, et al. Crystal morphology of anatase titania nanocrystals used in dye-sensitized soalr cell. Cryst Growth Des, 2008, 8: 247-252

15 Lan Z, Wu J H, Lin J M, et al. Inflnence of molecular weight of PEG on the property of polymer gel electrolyte and performance of quasi-solid-state dye-sensitized solar cells. Electrochim Acta, 2007, 52: 6673-6678

16 Hao S C, Wu J H, Fan L Q, et al. The influence of acid treatment of $\mathrm{TiO}_{2}$ porous film electrode on photoelectric performance of dyesensitized solar cell. Sol Energy, 2004, 76: 745-750

17 Zhang X K, Wu J H, Li S Q, et al. Preparation of nano-crystalline $\mathrm{TiO}_{2}$ porous film electrode using a mixing P25 hydrothermal method. Chinese J Imag Sci Photochem, 2008, 26: 499-506

18 Kang Y C, Park S B, Lenggoro I W, et al. $\mathrm{Gd}_{2} \mathrm{O}_{3}$ :Eu phosphor particles with sphericity, submicron size and non-aggregation characteristics. J Phys Chem Solids, 1999, 60: 379-384

19 Garcia-Murillo A, Luyer C L, Dujardin C, et al. Elaboration and characterization of $\mathrm{Gd}_{2} \mathrm{O}_{3}$ waveguiding thin films prepared by the sol-gel process. Opt Mater, 2001, 16: 39-46

20 Yang J, Li C X, Cheng Z Y, et al. Size-tailored synthesis and luminescent properties of one-dimensional $\mathrm{Gd}_{2} \mathrm{O}_{3}: \mathrm{Eu}^{3+}$ nanorods and microrods. J Phys Chem C, 2007, 111: 18148-18154

21 Blasse G, Grabmaier B C. Luminescent Materials. Berlin: SpringerVerlag, 1994

22 Liu Y, Shen H, Huang X R, et al. A new improved structure of dye-sensitized solar cells with reflection film. Chinese Sci Bull, 2006, 51: 369-373

23 Ko H K, Lee Y C, Jung Y J. Enhanced efficiency of dye-sensitized $\mathrm{TiO}_{2}$ solar cells (DSSC) by doping of metal ions. J Colloid Interface Sci, 2005, 283: 482-487

24 Yang S M, Kou H Z, Wang L, et al. Photoelectrochemical properties of $\mathrm{N} 3$ sensitized $\mathrm{Ho}^{3+}$ modified $\mathrm{TiO}_{2}$ nanocrystalline electrodes. Acta Phys Chim Sin, 2009, 25:1219-1224

25 Yang S M, Li F Y, Huang C H. Photoelectrochemical properties of dye sensitized rare-earth ions modified $\mathrm{TiO}_{2}$ nanocrystalline electrodes. Sci China Ser B-Chem, 2003, 33: 59-65

Open Access This article is distributed under the terms of the Creative Commons Attribution License which permits any use, distribution, and reproduction in any medium, provided the original author(s) and source are credited. 